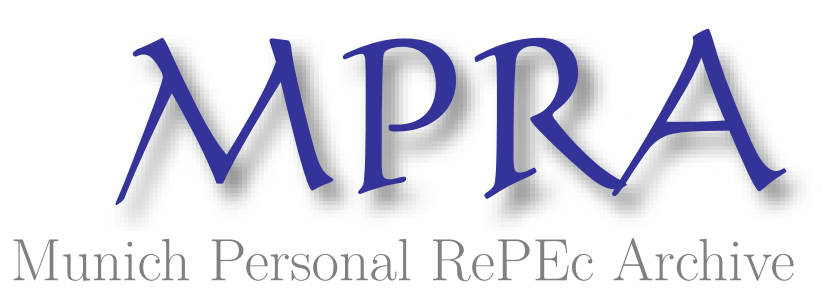

\title{
What Is "Open"? An Economic Analysis of Open Institutions
}

\author{
Deng, Feng
}

10 January 2008

Online at https://mpra.ub.uni-muenchen.de/8888/

MPRA Paper No. 8888, posted 29 May 2008 03:15 UTC 


\title{
What Is "Open"?
}

\section{An Economic Analysis of Open Institutions}

\author{
Feng Deng* \\ January 10, 2008
}

* School of Economics \& Business Administration, Chongqing University, Chongqing, P. R. China. Email:dengfengf@gmail.com.

I thank Lanlan Wang and Tianxin Zhang, who were initially co-authors, for their helpful discussion when we started this paper together. I am also grateful to Su Xiangui for introduction to the history of science. All remaining errors are my own. 


\title{
What Is “Open”?
}

\section{An Economic Analysis of Open Institutions}

\author{
(ABSTRACT)
}

By examining several different types of open institutions including open source software, open science, open square and (open) urban planning, this paper presents a general analysis of open institutional structure that is complementary to traditional proprietary mode. We argue that open institutions, in whatever forms, are essentially about decentralized production of a collective good (or "commons") that relies on voluntary collaboration of highly variable humanrelated input. In addition to providing a general definition of open institutional structure, we submit there are two necessary conditions for open institutions. The first is the integration of consumers into production. The second condition is that the efficiency gain from "production" commons is the objective and the tragedy of anticommons becomes a serious problem. In this sense, open institutions represent a positive approach toward externality and uncertainty.

KEYWORDS: $\quad$ open institutions, collective good, open source software, open science, open square, urban planning

JEL: $\quad$ D23, D71, H41, L22, L31, R52 


\section{INTRODUCTION}

Nowadays open society, open access, open source software, open space, and so on are all popular terms in our daily life and in academic writings. More or less, many people are using them in a positive sense. But, what does "open" exactly mean? Can we identify a common institutional structure across the many different open institutional arrangements? ${ }^{1}$

The conventional wisdom in property rights or even institutional theories is that when the costs of delineating or defining property rights are higher than the benefits, then it is beneficial to leave it in the public domain or the "open" form of institutions. This could be called a "residual theory" for open institutions that simply equates "public" to "open". In other words, only when private property rights arrangement cannot solve the problem (through internalization of externality, Coasian transaction, and so on) do we resort to open institutions. But, there have been many challenges to this view. For example, in a recent paper by North, Wallis and Weingast (2006), “open" means unfettered competition in economic and political arena. By regarding open institutions as the fundamental structure for the latest stage of human society, their argument suggests a positive view of open institutions and casts doubt on the traditional wisdom. .

In the literature on urban property rights and institutions, one main type of institutional structure is the integration of property owner and collective goods provider in the form of political or economic organizations (Beito, Gordon and Tabarrok 2002; Deng 2003a), such as homeowners association, shopping malls, and even suburban local government (Fischel 2001). The implicit implication of this line of reasoning conforms to the residual theory (see, for example, Webster and Lai 2003). On the other hand, diversity and externality's positive role has

\footnotetext{
${ }^{1}$ Following North, Wallis and Weingast (2006), I distinguish institutional structure from organizations. Institutional structure is what is common across many seemingly different organizations in a society. In this sense, institutional structure is more fundamental than the general term of institutions in defining the rule of games.
} 
been emphasized, albeit rather separately from most formal theories, in the urban literature (Jacobs 1961). One question arises: do open institutions represent another fundamental institutional structure in urban area, or more generally, in our economy?

In the present paper, we explore the following research questions. First, what characterizes so-called open institutions? In other words, we want to identify the institutional structure common to the many different forms of open institutions. We want to explore an accurate and rigorous definition of open institutions and, hence, the possibility to study this concept. Second, what are the economic benefits of open institutions? In this way, we can better understand where and when we need to have open institutions rather than traditional proprietary institutions.

Open institutions could be found in a wide variety of fields and exhibit many different forms. For example, Benkler (2002) studied the phenomenon of "commons-based peer production" that is characterized by "large-scale collaboration in many information production fields ... in the digitally networked environment without reliance either on markets or managerial hierarchy" (Benkler 2002: 374). His survey of the fields include NASA Clickworkers, K5, online games, the system in Amazon to rate books, Google's rating of web sites, Slashdot, Napster, and many others. In our view, they represent to different degrees open institutions that have been emerging due to the development of information technology. In this paper, we focus on four different fields as typical examples of open institutions in order to obtain some general conclusions about this fundamental institutional structure.

In the present paper we submit a general definition of open institutional structure. In contrast to conventional institutional and property rights theories that focus on transaction and 
contract, we argue that open institutional structure is really about production. Our approach obviously implies a positive view on externality and uncertainty.

In analyzing the economic reasons for open institutions, we focus on three basic aspects: (1) the final product of open institutions; (2) integration of consumers into production; (3) why are open institutions superior to proprietary structure in some situations? These three aspects correspond to some fundamental questions about open institutions: what do they produce? How are people motivated to participate in open institutions? When and why can people better collaborate to work together in open institutions than in a proprietary world?

We argue that what is produced by open institutions must be a collective good, with no clear direction for the final product and relying on highly variable human-related input. Integration of consumers into production is a necessary condition. It also means that the "production" commons in the sense of Fennell (2004) is more important in situations where open institutions are superior to the proprietary mode than vice versa. By avoiding the anticommons problem in a proprietary world, open institutions can effectively help people to collaborate in producing a better commons.

The next section of this paper presents a brief review of four different types of open institutions, namely, open source software, open science, open square and modern (open) urban planning. Then we summarize a common definition of open institutions in the third section. The fourth section includes several hypotheses we develop in order to understand the economic reasons for open institutions. The last section includes more discussion and the conclusion.

\section{OPEN INSTITUTIONS}


In this section we briefly review several major types of open institutions we are interested in, including open source software, open science, open (urban) square, and the institution of modern (open) urban planning. Our focus is on the basic structure of their institutional arrangements instead of those features unique to their respective fields. Our objective is to reach some general definition of open institutional structure.

\section{Open Source Software}

Open source software (OSS) is one of the most important developments in industrial organization in recent decades and the most widely studied among our examples of open institutions. The most famous examples include Apache web server and Linux operating system. The fundamental concept of OSS is that there should be unrestricted access to the source codes and anyone could modify the codes and circulate them without being restricted as in the traditional proprietary system. ${ }^{2}$

Although OSS has a long history, its first important milestone was the establishment of the Free Software Foundation by Richard Stallman in 1983. An important institutional innovation that was first introduced by the Free Software Foundation is a formal licensing procedure (General Public License, GPL). In 1995, Debian, an organization set up to disseminate Linux, developed the "Debian Social Contract" that evolved into what is now known as "Open Source Definition". This licensing arrangement allows greater flexibility, including the right to bundle open source software with proprietary code.

Lerner and Tirole (2000) think that many OSS phenomena can be explained by simple labor economics. In particular, they argue that OSS participants may be motivated by the

\footnotetext{
${ }^{2}$ OSS is different from shareware or free software. Shareware is only freely available in the binary form and its underlying source code is not openly accessible. Freeware (or public-domain software) has no restrictions placed on subsequent users of the source code.
} 
following rewards: (1) fixing bugs or customizing programs for their own benefits; (2) lowering cost to programmers due to Alumni effect; (3) career concern incentive; (4) ego gratification incentive. In general, the literature largely agree that in OSS performance measurement is better and easier and the performance is more informative of talent; OSS programmers take full responsibility while within a firm their performance depends on others; capital formed in OSS is also less firm-specific but rather more human-specific. The evidence for these arguments includes the importance of user benefits, accrediting programmers and reputation to developers in open source projects. ${ }^{3}$

Existing studies on OSS often focus on its different aspects. For example, Kuan (2001) is probably the first to formally model open-source software as a make-or-buy problem that results in the integration of consumers and producers. When users organize to produce a good for themselves, its quality will be higher than closed source software. Kuan's approach somehow simplifies the institutional structure of OSS by ignoring that the good is a collective good and its production needs collaboration of many people. In a different approach, Benkler (2002) emphasizes "commons-based peer production" in OSS that is regarded as a distinct mode from market and the firm. ${ }^{4}$

\section{Open Science}

Many researchers have noted the similarity between OSS and modern science, which is also called "open science", "public science", or even "the Republic of Science" in contrast to the

\footnotetext{
${ }^{3}$ For a recent review and a collection of studies on OSS, see von Krogh and von Hippel (2006).

${ }^{4}$ Benkler's approach focuses on information economy brought about by OSS. However, first, the role of user as producer is largely ignored. Second, in spite of the well-known advantages of internet on information exchanges and flows, people can also communicate efficiently by talking to each other. That is one reason why workers and assets are often concentrated inside one physical building. Of course, there is no doubt that internet has some unmatched advantages to facilitate intra-production collaboration, but this factor is not fundamental to the structure of open institutions, especially in fields that do not produce information.
} 
proprietary mode of developing knowledge (David 1998). Most scientific research are now carried on by universities or public institutes and supported by state funding. It is characterized by free and wide communication of research results, peer evaluation and voluntary participation in the sense that there is no constraint on the direction of research.

Largely from the perspective of externality, Nelson (1959) discusses the relationship between basic scientific research and why few private firms, except a few with large technological base, would be expected to invest in basic research. Examining the emergence of open science from an institutional and historical perspective, David (1998) argues that the informational problem faced by the patrons in a new age of science led to the institutional form of open science. In particular, he argues that scientific research was first made possible due to the old system of aristocratic patronage. But later on with the development of the new mathematical form of "mechanical philosophy", evaluation of scientific products became difficult and various principal-agent problems ensued. The competition among noble patrons for prestigious clients gave rise to the institutional form of open science, which features the norms of cooperation and information disclosure within the community of scientists, and their institutionalization through formal scientific organizations. ${ }^{5}$

An interesting issue emerges in recent years after many governments encourage universities to patent their discoveries, especially in biomedical field. This privatization of research has certainly strengthened the incentives of scientists, but Heller \& Eisenberg (1998) pointed out that privatizing "up-stream" research in biomedical field may result in anti-commons problem that is socially inefficient. Again, we see a delicate balance between proprietary mode of scientific research and the open structure.

\footnotetext{
${ }^{5}$ Given the importance of religion in European history, no doubt it also played an important role in the development of modern institutions of scientific research ( $\mathrm{Su} 2000)$.
} 


\section{Open Square}

Cities have many public squares. An intriguing question is why squares are public? This question becomes important if we consider two issues. First, some private communities also have "private" squares in the sense that they are only accessible to residents within those communities. Second, some squares built by private parties are designed to be public. One example is the SONY Square in Berlin. ${ }^{6}$ It was built by private company, but designed to be open to the public, and most visitors are people who visit a nearby movie museum instead of those who work in the surrounding office buildings owned by the company. In the case of SONY Square, a natural question is why the square is designed to be open. A seemingly more reasonable approach is to have a private square that serves only people who work in the office buildings. From the perspective of property rights, it seems strange for a property owner to intentionally open up part of his property, giving everybody a right of "trespassing" on that property. Designers' justification usually includes that an open city square is livable and is, therefore, an amenity to office buildings. In other words, an open square in the case of SONY Square is more valuable to the whole project than a private square.

Interestingly, when Fennell discussed tragedy of commons, she also used an example of people shopping in a downtown Main Street instead of a cheaper suburban shopping centers (Fennell 2004: 924). Obviously, the busy, warm and livable urban atmosphere, just as described in Jacobs (1961), provides consumers a sense of enjoyment that might be offset by higher price in a downtown street.

With the rapid development of shopping malls and shopping centers, many "private" squares inside them also gradually become a gather-together place for kids. Nevertheless, most

\footnotetext{
${ }^{6}$ I thank Tianxin Zhang for providing this example.
} 
visitors to these "private" squares are consumers who are shopping in the malls. This is very different from a real open square in city, where visitors may go for many different purposes and no restriction can be imposed on their accessibility. Of course, nothing is black and white; there is a degree of difference here. Many squares may not be fully open but with managed access by the public.

\section{Open Urban Planning}

Modern form of urban or city planning is also a good example of open institutions.

Before its introduction, private covenants were the major mode of land-use control (Siegan 1972; Beito 2002; Davies 2002). Many private deed restrictions in England were imposed by the original big landowners, usually nobility and other landed gentry (Davies 2002). The emergence of urban planning in the early 20th century indicates the problems of private covenants in landuse control. Even some writers less begrudging of private property have noted problems with private covenants (see, for example, Beito, 2002; MacCallum, 1970).

The rise of urban planning responded to the need for public good, especially public health and crime, in UK or to the need for solving externality problem in the US (Hall 2002). Deng (2003b) argues that the eclipse of private covenants illustrates the impossibility of comprehensive contract.

In addition to its various technical developments, modern urban planning is characterized by voluntary public participation, a clear sense of urban commons, decision by political majority, and enforcement by police power. Its governance structure in many countries corresponds to the political hierarchy in the sense that there is also a hierarchy of planning at different spatial scales, although the strength of this relation varies in different countries. The world-wide development 
of modern urban planning in the early twentieth century suggests that its institutional form has some advantages over traditional proprietary mode.

The rebound of private zoning in recent decades worldwide shows that proprietary institutional structure, as complementary to open structure, has also responded to some inherent problems in modern urban planning (Deng 2003b). These new proprietary institutional forms may represent a new trend for urban institutions (Beito, Gordon and Tabarrak 2002).

\section{Open Institutions Are Really about Production}

A brief look across the above examples gives us some preliminary clues about open institutions. Conventional theories of property rights are almost all about transaction. Although different property rights arrangements may have different implications for production, such as this owner being better at using this property than another owner, they don't directly determine or affect the mode of production. But, open institutions are really directly about production instead of transaction. For example, OSS is not about free access to the source code, which by itself is nothing different from free copying of compiled binary codes, the final format of commercial software products. The essence of OSS is how different people can fix, improve or build upon the source codes so that a big software "project" can be achieved in a voluntary, free access environment. Kogut and Metiu (2001) pointed out that an important dimension of OSS is a production model. ${ }^{7}$ It can be characterized as decentralized decision making (regarding who, how, when to improve on the source codes), albeit under some voluntary governance structure, and decentralized collaboration and production. In contrast, conventional production mode is characterized by centralized decision making and centralized production (in terms of people, time and space).

\footnotetext{
${ }^{7}$ Another dimension that they refer to is public ownership of intellectual property.
} 
Although the case of public square is less obvious, its essence is still about production. What SONY wants in the design of the square is a social or "livable" square that includes not only the physical square but also different types of people and the random combinations of their activities in the square. In this sense, all people who visit the square also contribute to the production of this "livable" square. The product of this unintended collaboration of different people at different time is an ever changing picture or atmosphere of the square.

In this sense, peer collaboration itself is not the distinct feature of open institutions, as emphasized by Benkler (2002). For example, Microsoft employees collaborate both formally and informally (such as by talk and other social activities) in their work places. This collaboration is based on (labor) market transactions that rely on employment contract. Outsourcing can also be a form of collaboration that depends on commercial contract. On the contrary, in the case of Linux, people cooperate in production not due to any contract; it is often said to be based on so-called "common interest" or "commons". So, it is the voluntary and decentralized nature of peer collaboration that distinguishes open institutions.

This raises an interesting question: in open institutions, what motivate people to participate in production without much monetary incentive? Since participation in commons or provision of public good has long been a big problem in public economics and organizational economics (see, for example, Olson 1965), this question can also be framed in another way: under what conditions can open institutions become an effective mechanism for participation in commons?

Traditional theories of property rights look at open institutions mostly from a transactional perspective, while many studies on OSS are restricted within information industry, 
therefore limiting the general appeal of their conclusions. One of this paper's main objectives is to look for a general definition of the open institutional structure.

\section{THE INSTITUTIONAL STRUCTURE}

Conventional wisdom often simply equates open institutions to open access. This may be misleading if it is only understood to be free access to a resource. For example, "open space" is a planning concept that emphasizes access to a wide area of farmland or forest for scenic view or wildlife preservation. But, it is based on physical attributes of land use instead of a particular institutional arrangement. Open space can be in the form of private property rights (McLeod, Woirhaye et al. 1998) or public ownership. In this sense, it is a planning objective rather than an institutional arrangement. Therefore, we do not include "open space" into our definition of open institutions. We can see from this example that two major dimensions are both necessary to describe open institutions: first, what to access; second, how to access.

Open institutions are about production of a collective good. What is open is access to the production process. In spite of some arguments for the importance of production (Langlois and Foss 1997), most existing studies on organizations and institutions focus on transactions. The typical approach is to minimize transaction cost, as studied by Coase (1991), Williamson (1985), Hart (1995) and many others. The recent growth of OSS certainly points to the importance of production in understanding open institutions. Many researchers have noted that OSS is a production model that exploits the distributed human capital and relies on their collaboration (Kogut and Metiu 2001; Benkler 2002). Although our understanding of market, hierarchy, and the firm can be synthesized in a framework of transaction cost in the vein of Coase (1991), open institutions are clearly different. They are contrary to transaction. 
In open institutions, access should be open and free. Therefore, they are contrary to property rights in the sense that they are not dependent on any proprietary mode of production or transaction. "Open-source development exists because, once property rights are removed from consideration, in-house production is often revealed as less efficient" (Kogut and Metiu 2001:249). One issue merits clarification. Open institutions do not necessarily imply fragmentation of property because there is no role of property rights at all. ${ }^{8}$ Hence, many traditional discussions on externality, which arise due to fragmented property rights and could potentially be mitigated by various property rights arrangements (Coase 1960), are not very helpful here because externality is not regarded as a problem but rather an important source of productivity in the open structure mode.

Open institutions are also contrary to contract, which is used to facilitate transactions in a world of property rights. There is no doubt of the importance of contract in modern market economy. The question is why we need an institutional arrangement that does not rely on contract or even transaction.

In light of the above discussions, the definition of open institutional structure includes the following elements:

- Open access to the production process (including decision making and production) for a collective good.

- No property rights or proprietary rules.

- No contract is involved in the "open" process. Voluntary participation.

\footnotetext{
${ }^{8}$ Fennell (2004) has a good discussion of the reasons and consequences of property fragmentation. She identified some positive reasons for fragmentation: (1) fragmentation may be important for people to relinquish power over the resource without actually transferring the power or property; (2) it might be a way to temporarily force the negotiation to spread over people or generations, during which more information can be collected and information asymmetry could be avoided.
} 
- Consumers are also producers, i.e., the integration of consumer and producer.

According to this definition, it is clear that open space does not belong to open institutions. It includes merely the word "open" in its original meaning. Can "freeware" be regarded as a type of open institutional arrangement? Can the so-called "flexible production" be counted as open institutions? The answers to these two questions are probably both negative. Freeware is only open in the transaction process because users can only download the binary codes and cannot get involved in its production. Although flexible production allows submission of customized orders, it is also only open in the transaction process and directly relies on contract and property rights.

It is necessary to distinguish among several pairs of confusing terms. First, open institutions are different from public institutions. The latter emphasizes more on public ownership and many open institutions are not dependent on public ownership. Open institutions have no property rights at all. Second, open institutions are also different from non-profit organization. The latter usually refers to a small set of organizations to which the objective is not profit maximization but which are still based on property rights. Although the motivation for people to participate in open institutions usually does not include direct monetary incentives, their basic structure may be quite different from many non-profit organizations. When these two forms overlap, non-profit organization such as Free Software Foundation often serves as the governance organization. Lastly, open access in the transaction process is basically competition in the market, as we commonly understand. That's another reason why we exclude the transaction process from the definition of open institutional structure. 


\section{WHY “OPEN"?}

To understand why open institutions exist is the same as understanding under what conditions they could be more efficient than the proprietary mode of production. One objective of this paper is to identify factors leading to open institutions instead of resorting to "residual theory" that is based on the proprietary structure. We focus on three fundamental questions about open institutions: (1) what is produced? (2) Why are people motivated to participate in the open institutions? (3) How do people coordinate to work together?

Many existing studies (see, for example, Lerner and Tirole 2000; Bonaccorsi and Rossi 2002) on OSS focus on the second and third questions, probably because the answer for the first question is very obvious in a particular field. In order to have a general understanding of the reasons for open institutions, the first question then becomes crucial since open institutional structure may only be efficient when producing some particular types of goods.

The second question is related to the theories on collective good, such as Olson's theory (1965) on group and organization. Olson argues that the incentive to participate in the provision of a collective good declines with the size of the group and, therefore, the organization or group must provide some private benefit to its members. It is worth noting that some other arguments, such as labor economics theories suggested by Lerner and Tirole (2000) in the case of OSS, do not necessarily contradict theories on the provision of collective good.

Studies related to the third question often focus on vertical structure or the general governance mechanism for open institutions. If that were the only difference between them, then open institutions wouldn't be much different from proprietary form. The one missing piece that distinguishes open institutions from proprietary form is the removal of property rights from the coordination mechanism for people to work together. Another aspect of the third question is the 
relationship between open institutions and the proprietary structure. In our view, open institutions are an antidote to the problems in a proprietary world that prevent people from collaborating to work together.

\section{Collective Good}

It is almost common sense that open institutions are related to collective good as the term "commons" is often used in the related research. ${ }^{9}$ Given the wide variety of institutional forms in providing collective good, a natural question is what type of collective good should be provided by open institutions.

Hypothesis 1: the product of open institutions must be collective good; there is no clear direction for the final product; its decentralized production relies on highly variable humanrelated input that requires high motivation from at least some people, who are difficult to identify ex ante, and doesn't rely on large investment of physical capital.

The best example to illustrate the central role of collective good for open institutions is GPL, the formal licensing procedure that requires all subsequent modifications and development of open source software must also remain open. Information product is special because it is a bundle of private good and collective good. In the case of software, the private good is the media such as CD or hard disk; the collective good is the content such as source code or binary code. Since the source code can be easily modified or improved, GPL effectively prevents the software program from becoming a private good, which could be used by its owner for private benefits. In other words, when the product is a private good, the incentive structure for open institutions collapses.

\footnotetext{
${ }^{9}$ In this paper we use the term "collective good" instead of "public good" because the latter has a stricter definition (non-excludability and non-rivalry in consumption) and is often associated with public institutions.
} 
The final product of open institutions should also have no clear ex ante direction, roadmap or design. There are several possible reasons for this. First, the nature of some products may directly depend on the randomness or variability of its final format. Open urban square is a case in point. What we desire is a livable square that changes every minute and cannot be accurately predicted (in terms of people and activities inside it). If we know in advance whom we are going to meet and what we are going to see in a square, that is a boring place without any attraction. Second, the final form of the collective good, if it exists at all, may simply be unpredictable given the limit of human knowledge. This point is most obvious in the case of open science. Third, if the final product has clear direction then it will be easy to organize its production through contract, the main transactional format in a proprietary world. In other words, the proprietary mode will be more efficient than open institutional structure.

The unpredictability or variability of its final product implies that production in open institutions must be highly human specific and decentralized. For information product and especially its variability, which is the primary source of efficiency gains for OSS, many researchers have noted the central role of human capital in its production (Benkler 2002). The highly variable nature of human capital is the source of innovation and creativity. Whenever human-related input to the production is not highly variable, then proprietary mode may become more efficient. A good example is urban planning and private community. When the population in a community (or city) is highly heterogeneous, as in most cities around the world, "open" urban planning is the dominant form. When the community becomes very homogeneous due to either smaller size or Tieboutian sorting, we see the rebound of private community that is based on property rights (Deng 2003b). 
If large investment of physical capital is needed and if human input is relatively standard in the form of large-scale teamwork, then proprietary mode may be more efficient than open institutions. Open urban square requires little physical capital other than the presence of human beings. The same is true for software industry. "[I]n many industries, the development of individual components requires large-scale teamwork and substantial capital costs, as opposed to (for some software programs) individual contributions and no capital investment (besides the computer the programmer already has)" (Lerner and Tirole 2005:115). In other words, large physical capital investment makes it economical to concentrate workers together and standardize their input.

Given its nature of open access and voluntary participation, the success of open institutions depends crucially on high motivation of at least some of the members. This is where open institutional structure connects to theories on collective good and organization. For example, Olson (1965) thinks that, because people's incentive to participate in the provision of collective good decreases with the group size, it has to provide some private benefits to its members. Given the unlimited size of open institutions, Olson's argument means that, on the one hand, direct material incentives necessary to bring about contribution must be trivial and, on the other hand, there must be some private benefits to some members who are highly motivated. It is because of this inherent problem in providing collective good and also the variable and unpredictable nature of the collective good that voluntary participation and free exit become necessary structure for the sustainable development of open institutions.

\section{Consumer and Production}


Many researchers have observed that most participants in OSS are also its users. In open science, most consumers of scientific discoveries are also researchers who share their findings through peer review and open publications. The rise of urban planning in the early twentieth century was intended to solve various urban externalities that affect residents in the city, who also participate in planning either indirectly through the political process or directly by attending public hearings. In the case of open urban square, the presence of visitors directly contributes to the creation of a livable square. Of course, the question is why open institutions feature the integration of consumer into production.

Hypothesis 2: integration of consumers into production, to different degrees, is a necessary condition for the efficiency of open institutions.

There are several possible reasons for the integration of consumer into production in open institutional structure. First, the final product of some open institutions is directly dependent on the consumers. The best example is open square. Visitors (consumers) are simultaneously part of the final product - the livable urban square — and its producers.

Second, integration of consumers into production can guarantee that there are some private benefits to at least those consumers of high performance in contribution. As Olson (1965) suggests, there must be some private benefits to group members since the incentive for their participation will otherwise be too low to sustain. Given the absence of monetary incentive within open institutional structure, integration of consumers and producers can help to provide some direct non-monetary incentives such as fixing bugs, customizing programs, and even reputation and career incentives. Lerner and Tirole (2000) listed some private rewards to OSS participants that fit into simple labor economics. In their empirical studies on the factors that determine the scope of open source licensing, they found that restrictive licenses are more 
common for applications geared toward end-users and less likely for those oriented toward developers (Lerner and Tirole 2005). ${ }^{10}$ In other words, open source licensing tends to be more open and less commercial when the consumers are more integrated into production. In open planning, many have observed that the most active participants in planning process are those homeowners whose property values may be directly affected by planning. Their motivation may be due to rent capitalization (Fischel 2001) or the political hold-up problem (Deng 2003a).

Third, the integration of consumers and producers is to some extent similar to "userdriven innovation" in some industries such as machine tool instruments and scientific instruments (von Hippel 1988). This shows the importance of highly variable human capital and creativity to open institutions. Human capital is certainly related to consumer's experience of using the product. In the case of open planning, only local residents who will be most affected have the best local knowledge that is vital for a good plan. In OSS, users are more familiar with the features and problems of the software and, hence, are better at designing and improving the software. For example, Kogut and Metiu (2001) noted an efficiency gain from OSS model is concurrent debugging and design. Kuan's (2001) empirical study also points to the efficiency of OSS in debugging code. She built a formal model that analyzes consumer's choice between commercial software and adapting open source code to his or her own use. She found that the quality of OSS can be expected to be higher than their commercial counterparts.

\section{Anti-commons Problem}

We have so far analyzed what is produced by open institutions and how people are motivated for participation, but we don't know why proprietary mode is not efficient in

\footnotetext{
${ }^{10}$ In their study they classifies licensing into two types: restrictive ones that require modification of the program must make the source code available; highly restrictive ones that prohibit modification of the open source program from mingling with other non-open source software.
} 
situations where open institutions thrive. Alternatively, we need to know what problems make the proprietary mode inferior to open institutions in those situations. The answer to this question is basically about how people can best coordinate to work together in different situations.

In recent years the academic interest in anticommons problem has surged in analyzing various problems resulted from the fragmentation of property rights (Heller 1998; Buchanan and Yoon 2000). Simply put, the commons problem is due to "the right to use significantly exceeds the effective right (or power) to exclude others", while in anticommons problem, "the coowners' right of use is mitigated, and potentially eliminated, by an eclipsing right of exclusion held by competing co-owners" (Parisi, Schulz and Depoorter 2004:176). Tragedy of commons and tragedy of anticommons are often regarded as duality (Buchanan and Yoon 2000).

In a well-thought paper, Fennell (2004) tries to synthesize them instead of treating them as dichotomous problems. She uses an umbrella term "common interest tragedy" for both the tragedy of commons and the tragedy of anticommons, and suggests two basic requirements to identify a common interest tragedy. First, the individuals must fail to internalize all the costs or benefits of their actions. In other words, there must be externalities in using the resource.

Second, the total returns to the group must be larger in the case of cooperative action than in the case of defecting action. Most importantly, Fennell (2004) points out the connection between the tragedy of commons and the tragedy of anticommons by noting that, in addition to the fixed common resource, there is another "commons" that is relevant to the participants' payouts-the resource-gathering environment. This is in the same spirit as our emphasis on the production benefits associated with open institutions. ${ }^{11}$

\footnotetext{
${ }^{11}$ Fennell (2004) appears to think that the purpose of the second requirement is to distinguish between efficiency and distribution. This point is evident in her definition of the "common interest tragedies". We would rather argue that this important role of production (or efficiency, in the terminology of Fennell) is crucial for open institutions.
} 
[A] tragedy of the commons (the tendency to overgraze the air) can morph before our eyes into a tragedy of the anticommons once we take note of the fragmentary interests that facilitate the overgrazing and consider the possibility of putting them together under one person's control to stop it from happening. Indeed, any tragedy of the commons contains within it the potential for a surplus associated with moving from universal defection to universal cooperation. To simplify a little, the tragedy of the commons tells us why things are likely to fall apart, and the tragedy of the anticommons helps explain why it is often so hard to get them back together. (Fennell 2004: 936)

Hypothesis 3: given the convergence of commons and anticommons in the sense of Fennell (2004), open institutions are most efficient when the "production" commons is more important and the tragedy of anticommons becomes a serious problem in proprietary mode.

The "production" commons is the total gains when the group members cooperate in production, in whatever sense, instead of pursuing fragmentary interests in non-cooperative actions, which can result in the tragedy of commons. When the total gains from the "production" commons are significant, then the tragedy of anticommons that is associated with the "production" commons in a proprietary world will become a serious concern. The reason why "production" commons is very important for open institutions is its integration of consumers into production. If they are separate, then the tragedy of commons may be an important issue for the consumers who simply consume the final product, a collective good. Then, the tragedy of anticommons may not be an issue at all because there is no possibility for them to get involved in the production process. The issue of "production" commons is not very realistic or meaningful 
in this case. It is exactly due to the integration of consumers and producers that open institutions are related to the tragedies of commons, especially the "production" commons.

Open institutions are an antidote to the tragedy of anticommons because property rights are removed from the problem. Even in the Russian example as told by Heller (1998), it was the de facto property rights held by some interest groups that blocked the reform. In the case of software, proprietary firm tends to hold technological secrets in order to obtain more rent, but this prevents those technological "secrets" from being used by other firms. The owner has the incentive to dig in by increasing firm-specific capital, which leads to the hold-up problem or the anti-commons problem. ${ }^{12}$ In contrast, "using open source technology encourages users that they will not be 'held up' by a future price increase after adopting a technology and that they will always be able to tailor their technology to their own particular needs" (Lerner and Tirole 2005:115). Participation in OSS increases human-specific capital instead of firm-specific capital. The former would not cause anticommons problem due to the (voluntary) structure of open institutions. People who object to participating in the production commons are either vetoed (as in a political process) or allowed to exit voluntarily. In this case, the "production" commons is what could be achieved for the whole society by moving beyond simple universal access toward technological innovations.

Conceptually, in the case of software, there might be two ways to solve the anticommons problem. One way is to integrate all production processes and workers within one firm, such as in Microsoft. Theoretically, there is no anti-commons problem within the firm because no worker owns the source code and they have to follow the instructions from the governance hierarchy. But, Lerner \& Tirole (2000) noted that a firm's existing organizational structure may

\footnotetext{
${ }^{12}$ Some researchers have already noticed the parallel between anticommons and the hold-up problem (Parisi, Schulz and Depoorter 2004; Lerner and Tirole 2005). An obvious example that shows how public domain can help prevent the anticommons problem is the "property preempting investment (PPI)" (Merges 2004).
} 
pose obstacles to adopting open source system within a commercial firm. Each software development group within a firm appears to be very autonomous and do not like to share codes or technical information. Besides, software design cannot be separate from organizational structure, as found by many empirical studies. For instance, MacCormack, Rusnak and Baldwin (2006) found that the design structure of open source software is more modularized. Even if some similar type of peer collaboration can be implemented within a firm, it still couldn't have an essential feature of OSS: the integration of final users into production process. All these suggest that it would be difficult to emulate OSS within a commercial firm.

Let's also look at the case of SONY square. Assume that SONY could also build the square in a non-open, commercial and proprietary way. For example, SONY can hire many people to perform (or contract out) different types of social activities in the square. In that case, consumers are still integrated into production, albeit specified ex ante. However, one or a group of those employees or service firms may some day refuse to participate in the "production" process by holding up on some firm-specific or human-specific capital. In the presence of this type of anticommons problem, the final product will not be complete. Obviously, the open structure of the square helps to avoid the potential anticommons problem. ${ }^{13}$

The rise of modern open (and public) urban planning is also a good example to illustrate the function of open institutions to mitigate the anticommons problem. The problems of public health, security and so on in pre-twentieth century cities were mostly due to the failure of traditional land use controls, namely private covenants, to involve more people to take collective actions. On the one hand, multilateral contracting is difficult; on the other hand, a livable and growing city makes the proprietary mode difficult to cope with the uncertainty, variability and

\footnotetext{
${ }^{13}$ Of course, the imagined proprietary mode of production in this case still couldn't emulate the ever changing, livable feeling of an open urban square.
} 
even randomness (Deng 2003b). The new mode of land use control, open planning, adopted the open institutional form of political process and effectively resolved the tragedy of anticommons.

\section{DISCUSSION AND CONCLUSION}

This paper presents an attempt to have a general understanding of open institutional structure, which could be observed in many different fields of the society. By analyzing open source software, open science, open square and open urban planning, we argue that the essence of open institutions is production. This is in contrast to traditional studies on institutions and organization that focus on transaction, which is based on proprietary structure.

The open institutional structure is defined by open access to the production process, no property rights or proprietary rules, no contract, voluntary participation, and the integration of consumers and producers.

What is produced by open institutions is a collective good with no clear direction for the final product and relying on highly variable human-related input. Integration of consumers into production is a necessary condition for effective participation and product quality in open institutions. Integration of consumers and producers also means that the "production" commons is more important in the sense of Fennell (2004). Given the anticommons problem related to the "production" commons in a proprietary world, open institutions can effectively get around the anticommons problem that prevent people from collaborating to achieve a better commons.

There are also some fundamental issues about open institutional structure that deserve more discussion. First, many popular arguments about open institutions are normative in nature. This is most obvious in the debate about OSS. Words like "freedom" are flying everywhere. The nature of open institutions is indeed about freedom and voluntary participation. In this sense, 
open institutional structure may also have an inherent normative objective. Another aspect is equity, which is usually mentioned in contrary to commercial interest. For example, many think that proprietary format may be morally offensive to some people, especially those in fields that require high creativity. "[P]rivate claims to intellectual property right are often seen as morally offensive owing to their distributional consequences and the fact that excluded groups are deprived of the benefits" (Kogut and Metiu 2001:251). All these normative arguments should not be ignored in our analysis.

In a sense, open institutional structure is an efficient institutional form for the problem of externality. Many economists have found that the concept of externality is more difficult to be employed for analysis than that of public good or collective good (Cheung 1970). Given that most traditional studies more or less focus on proprietary mode and rely heavily on concepts like contract, firm and property, we think the reason for this analytical difficulty of externality is that the proprietary structure is inherently not a good institutional vehicle for dealing with widespread, variable and uncertain externalities. If OSS is a good example of how to make use of positive externalities, open urban planning is another one of how to control negative externalities.

The relationship of open institutions to the proprietary mode also involves many different considerations. The traditional wisdom appears to treat open institutions, sometimes called the public domain, as a residual form from proprietary world. In the same spirit of Fennell (2004), I would argue that the relationship between these two fundamental institutional structures is parallel to that between commons and anticommons. In situations where the tragedy of anticommons become a serious problem, open institutions is more efficient by avoiding various problems imbedded in property rights and contract; when the tragedy of commons become the concern, proprietary mode is better by leaving the production to an owner who retains all 
residual surplus. The latter manifests best in the growth of various forms of private communities (Beito, Gordon and Tabarrok 2002).

Many institutional studies (see, for example, Williamson 1985; Barzel 1989; Coase 1991; North 1991; Hart 1995) have shown that various institutional and property rights arrangements based on the proprietary structure evolve to deal with various problems from uncertainty. According to that perspective, uncertainty is regarded as negative (to transaction and its execution) and, hence, needs to be controlled. But, open institutions cast doubt on that conventional way of thinking. From our analysis in the present paper, it is easy to see that open institutions' production efficiency lies in exactly the uncertainty and unpredictability brought about by highly variable human capital. In other words, open institutional structure responds to the need to harvest the positive value of uncertainty.

On the other hand, open institutions reduce negative effects of uncertainty by resorting to the law of large numbers instead of contractual obligation. ${ }^{14}$ For example, if a programmer decides to stop his work on an OSS project, then the void could easily be filled by another voluntary programmer from the large number of volunteers in OSS. In a word, institutions respond to both negative and positive sides of uncertainty. Open institutions represent an approach to utilize the positive production efficiency of human creativity.

\footnotetext{
${ }^{14}$ Lee and Webster (2006) suggest that open-access urban commons is inherently unstable. We think that the change we observe to some urban commons may be due to changing environment. In other words, the change in the production mode may be an efficient response to changes in environment.
} 


\section{REFERENCES}

Barzel, Y. (1989). Economic Analysis of Property Rights. Cambridge, MA: Cambridge University Press.

Beito, D. T. (2002). The Private Places of St. Louis: Urban Infrastructure through Private Planning. Voluntary City. P. Gordon, A. Tabarrok and D. Beito. Ann Arbor: University of Michigan Press: 47-75.

Beito, D. T., P. Gordon and A. Tabarrok. (2002). The Voluntary City: Choice, Community, and Civil Society. Ann Arbor, MI, University of Michigan Press.

Benkler, Y. (2002). "Coase's Penguin, or, Linux and The Nature of the Firm." The Yale Law Journal 112(3): 369-446.

Bonaccorsi, A. and C. Rossi (2002). "Why Open Source Software Can Succeed." SSRN Working Paper.

Buchanan, J. M. and Y. J. Yoon (2000). "Symmetric Tragedies: Commons and Anticommons Property." Journal of Law and Economics 43: 1-13.

Cheung, S. (1970). "The Structure of a Contract and the Theory of a Non-exclusive Resource." Journal of Law and Economics 13: 49-70.

Coase, R. H. (1960). "The Problem of Social Cost." Journal of Law and Economics 13: 1-44.

Coase, R. H. (1991). The Nature of the Firm. The Nature of the Firm. O. E. Williamson and S. G. Winter. New York Oxford: Oxford University Press: 18-33.

David, P. A. (1998). "Common Agency Contracting and the Emergence of "Open Science" Institutions." The American Economic Review 88(2): 15-21.

Davies, S. (2002). Laissez-Faire Urban Planning. The Voluntary City. P. Gordon, A. Tabarrok and D. T. Beito. Ann Arbor, MI: University of Michigan Press: 18-46.

Deng, F. F. (2003a). "Collective Goods and the Political Hold-Up Problem." Journal of Institutional and Theoretical Economics 159(2): 414-434.

Deng, F. F. (2003b). "The Rebound of Private Zoning: Property Rights and Local Governance in Urban Land Use." Environment \& Planning A 35(1): 133-149.

Fennell, L. A. (2004). "Common Interest Tragedies." Northwestern University Law Review 98(3): 907-990. 
Fischel, W. A. (2001). The Homevoter Hypothesis: How Home Values Influence Local Government Taxation, School Finance, and Land-Use Policies. Cambridge, MA: Harvard University Press.

Hall, P. (2002). Cities of Tomorrow: An Intellectual History of Urban Planning and Design in the Twentieth Century. Malden, MA: Blackwell Publishing.

Hart, O. (1995). Firms, Contracts, and Financial Structure. Oxford: Clarendon Press.

Heller, M. A. (1998). "The Tragedy of the Anticommons: Property in the Transition from Marx to Markets." Harvard Law Review 111(3): 621-688.

Heller, M. A. and R. S. Eisenberg (1998). "Can Patents Deter Innovation? The Anticommons in Biomedical Research." Science 280(May): 698-701.

Jacobs, J. (1961). The Death and Life of Great American Cities. New York, NY: Random House.

Kogut, B. and A. Metiu (2001). "Open-source Software Development and Distributed Innovation." Oxford Review of Economic Policy 17(2): 248-264.

Kuan, J. (2001). "Open Source Software as Consumer Integration into Production." SSRN Working Paper.

Langlois, R. N. and N. J. Foss (1997). "Capabilities and Governance: the Rebirth of Production in the Theory of Economic Organization." DRUID (Danish Research Unit for Industrial Dynamics) Working Paper(97-2).

Lee, S. and C. Webster (2006). "Enclosure of the Urban Commons." GeoJournal 66: 27-42.

Lerner, J. and J. Tirole (2000). "The Simple Economics of Open Source " NBER Working Paper(7600).

Lerner, J. and J. Tirole (2005). "The Economics of Technology Sharing: Open Source and Beyond." The Journal of Economic Perspectives 19(2): 99-120.

MacCallum, S. H. (1970). The Art of Community. Menlo Park, California: Institute for Humane Studies, Inc.

MacCormack, A., J. Rusnak, et al. (2006). "Exploring the Structure of Complex Software Designs: An Empirical Study of Open Source and Proprietary Code." Management Science 52(7): 1015-1030.

McLeod, D., J. Woirhaye, et al. (1998). "Private Open Space and Public Concerns." Review of Agricultural Economics 20(2): 644-653. 
Merges, R. P. (2004). "A New Dynamism in the Public Domain." The University of Chicago Law Review 71(1): 183-203.

Nelson, R. R. (1959). "The Simple Economics of Basic Scientific Research." The Journal of Political Economy 67(3): 297-306.

North, D. C. (1991). Institutions, Institutional Change and Economic Performance. New York, NY: Cambridge University Press.

North, D. C., J. J. Wallis, et al. (2006). "A Conceptual Framework for Interpreting Recorded Human History." NBER Working Paper Series(12795).

Olson, M. (1965). The Logic of Collective Action: Public Goods and the Theory of Groups. Cambridge, MA: Harvard University Press.

Parisi, F., N. Schulz, et al. (2004). "Simultaneous and Sequential Anticommons." European Journal of Law and Economics 17(2): 175-190.

Siegan, B. H. (1972). Land Use without Zoning. Lexington, MA: Lexington Books, D. C. Heath and Company.

Su, X. (2000). "Christianity and Modern Science: from the Ecological Point of View." in Zhao, Dunhua eds., Christianity and Modern Chinese and Western Cultures. Beijing: Peking University Press.

von Hippel, E. (1988). The Sources of Innovation. New York, NY: Oxford University Press.

von Krogh, G. and E. von Hippel (2006). "The Promise of Research on Open Source Software." Management Science 52(7): 975-983.

Webster, C. and W.-C. Lai (2003). Property Rights, Planning and Markets: Managing Spontaneous Cities. Cheltenham, UK: Edward Elgar Publishing, Inc.

Williamson, O. E. (1985). The Economic Institutions of Capitalism. New York: The Free Press. 